\title{
Development of Probiotics Based Culture System of Macrobrachium rosenbergii Using Different Stocking Densities
}

\author{
Istiaq Ahmad Chowdhury*, Jewel Das and Nani Gopal Das
}

Institute of Marine Sciences and Fisheries, University of Chittagong, Bangladesh

\begin{abstract}
Owing to the problem of antibiotic resistance and subsequent reluctance of using antibiotics, probiotics use in aquaculture is becoming popular day by day. One experimental design with 150 days culture period of Macrobrachium rosenbergii was conducted with 3 treatments maintaining stocking density of $02 / \mathrm{m}^{2}, 03 / \mathrm{m}^{2}$ and $04 / \mathrm{m}^{2}$ in T1, T2 and T3 respectively. Each of the treatments was with 3 replicates where each replicate was segmented into two parts to separate probiotics and non-probiotics based culture system. The higher body weight of $63.7 \mathrm{~g}$ was recorded in lower SD of T1 in comparison to lower body weight of $55.7 \mathrm{~g}$ and $43.0 \mathrm{~g}$ in higher SD of T2 and T3 respectively for probiotics application segments. The average body weight of $55.7 \mathrm{~g}, 46.7 \mathrm{~g}$ and $37 \mathrm{~g}$ respectively were found for the same treatments in non-probiotics segments. The average survival rate of $69.3 \%, 62.7 \%$ and $58.3 \%$ were recorded in probiotics and $68.3 \%, 63 \%$ and $57.7 \%$ respectively in non-probiotics treatments. Average daily growth rate and gross production were found better in probiotics than that of non-probiotics segments in all the treatments. Average daily growth rate of $\mathrm{T} 1$ was found $0.41 \mathrm{~g}$ and $0.36 \mathrm{~g}$ respectively for probiotics and non-probiotics segments. Similarly, for T2 and T3 average daily growth rate were found $0.35 \mathrm{~g}$ and $0.27 \mathrm{~g}$ for probiotics and $0.30 \mathrm{~g}, 0.23 \mathrm{~g}$ for non-probiotics segments respectively. Gross average production showed better result of $103 \mathrm{~g} / \mathrm{m}^{2} / \mathrm{crop}$ in T2 probiotics treated segment than that of other two results of $87.23 \mathrm{~g} / \mathrm{m}^{2}$ and $98.10 \mathrm{~g} / \mathrm{m}^{2}$ in T1 and T3 treatments respectively where as $74.62 \mathrm{~g}, 87.23 \mathrm{~g}$ and $84.26 \mathrm{~g} / \mathrm{m}^{2} / \mathrm{crop}$ was recorded in T1, T2 and T3 respectively in nonprobiotics treatments. Abiotic parameters in all segments of 3 treatments were within the optimum ranges for $M$. rosenbergii culture during the study period.
\end{abstract}

Keywords: Probiotics; M. rosenbergii; Stocking density; Treatment; Production

\section{Introduction}

The most widely cultured fast growing two giant prawns in the globe including Bangladesh are Penaeus monodon and Macrobrachium rosenbergii. Their culture techniques are traditional, extensive, improved extensive, and mainly based on the stocking density of post larvae and management techniques of the culture ponds. Both monoculture as well as polyculture with fin fish (mullets, carps and tilapia) is the common practice in the South and Southeast Asian countries. Extensive and improved extensive polyculture are widely practiced in the freshwater environment throughout the country [1]. In Bangladesh, prawn farming can play an important role in poverty reduction by increasing job opportunity especially for the rural women that help to enhance their contribution to household income [2]. With increasing demand of environment friendly aquaculture, the use of probiotics in aquaculture is now widely accepted and recently, the use of probiotics to improve and maintain healthy environment for prawn culture has become popular in Bangladesh. Probiotics has been used to supply beneficial bacterial strains in rearing water that will help to increase microbial species composition in the environment and ultimately to improve water quality conditions [3]. This study attempted to make familiar with the fish farmer as well as farm owner's application of probiotics in the culture system of Macrobrachium rosenbergii and ultimately to minimize or totally stop the antibiotic application in farming system and finally draw the attraction of export market of the aquaculture products.

\section{Materials and Methods}

M. rosenbergii can be cultured in earthen ponds, concrete tanks, small reservoirs, cages, pens and paddy fields. In the present experiment, it was conducted in 9 ponds of two rural villages of Chittagong division, South-Eastern part of Bangladesh.

\section{Probiotics selection, mode of action, doses and usage instruction}

Methods of selection for probiotics use in Macrobrachium culture were considered the following steps:

1) Collection of background information

2) Acquisition of potential probiotics

3) Estimate the ability of potential probiotics to out-compete pathogenic strains

4) Assessment of pathogenicity of potential probiotics

5) Evaluation of effect of potential probiotics in culture and

6) An economic cost-benefit analysis and to check their availability in the market.

\section{Selection of commercial probiotics}

- Sanolife ${ }^{\bullet}$ Pro-1 was used by mixing with feed. Sanolife ${ }^{\bullet}$ Pro-1 contains specific mixture of strains of Bacillus spp. Minimum of $3 \times 10^{10}$ $\mathrm{cfu} / \mathrm{g}$. Standard Sanolife ${ }^{\circledast}$ Pro-1 application rates instructed $5 \mathrm{~g} / \mathrm{kg}$ feed.

- Biomin ${ }^{\circledR}$ Pondlife was another type of probiotics used in pond water. Biomin ${ }^{\bullet}$ Pondlife consists of Bacillus sp., Enterococcus sp.,

*Corresponding author: Istiaq Ahmad Chowdhury, Institute of Marine Sciences and Fisheries, University of Chittagong, Bangladesh, Tel: +880 1819-979279; E-mail: istiaq.ahmad11@gmail.com

Received July 03, 2017; Accepted July 20, 2017; Published July 22, 2017

Citation: Chowdhury IA, Das J, Das NG (2017) Development of Probiotics Based Culture System of Macrobrachium rosenbergii Using Different Stocking Densities. J Aquac Res Development 8: 494. doi: 10.4172/2155-9546.1000494

Copyright: (c) 2017 Chowdhury IA, et al. This is an open-access article distributed under the terms of the Creative Commons Attribution License, which permits unrestricted use, distribution, and reproduction in any medium, provided the original author and source are credited. 
Thiobacillus sp. and Paracoccus sp. Organic carrier product contains a minimum $2 \times 10^{10} \mathrm{cfu} / \mathrm{g}$. Instructed initial stage dose was $0.175 \mathrm{~g} / \mathrm{m}^{2}$ and final stage dose was $0.3 \mathrm{~g} / \mathrm{m}^{2}$ of pond area.

- Sanolife $e^{\oplus}$ Pro-W was the $3^{\text {rd }}$ type of probiotics used in the study. The product is a mixture strain of Bacillus spp. of minimum $5 \times 10^{10}$ $\mathrm{cfu} / \mathrm{g}$. Standard Sanolife ${ }^{\otimes}$ Pro-W application rate was instructed 0.02 $\mathrm{g} / \mathrm{m}^{2}$.

\section{Site selection and pond construction for freshwater prawn farming}

The experiment was conducted in two different rural areas of Chittagong division, South-Eastern part of Bangladesh. Total nine ponds were selected for the experiment from two different villages and size varies from $1200 \mathrm{~m}^{2}$ to $3600 \mathrm{~m}^{2}$. Among the nine selected ponds seven were old and two were newly excavated. Aquatic vegetation and weeds were eradicated from the old ponds. Weed fishes as well as predatory fishes were eradicated by drying the old pond bottom.

\section{Liming and fertilization}

Required amount of lime was applied into the ponds to make the desired $\mathrm{pH}$ level. Depending upon soil $\mathrm{pH}$, agricultural limestone was applied at $25 \mathrm{~g} / \mathrm{m}^{2}$ to $50 \mathrm{~g} / \mathrm{m}^{2}$. To increase the fertility and productivity of the ponds both organic and inorganic fertilizers were used. Raw cow dung was applied at $75 \mathrm{~g} / \mathrm{m}^{2}$ to $125 \mathrm{~g} / \mathrm{m}^{2}$ along with $6.25 \mathrm{~g} / \mathrm{m}^{2}$ triple super phosphate and $3.75 \mathrm{~g} / \mathrm{m}^{2}$ Urea. This application was continued for every 7 days interval up to the whole culture period.

\section{Increasing surface area}

Like many other crustaceans, $M$. rosenbergii shows strong territorial defense and hiding behavior. During molting, there is always a considerable risk of predation by larger dominant prawns. Hence, to increase habitat surface area and hiding, substrates are required to reduce predation in grow out ponds. Bushes, palm and coconut-leaves, bamboo, tiers, tree branches, etc. were used indigenously to provide substrates for prawns to cling and to hide in.

\section{Juvenile collection and stocking}

Good quality prawn juveniles were collected from a commercial private hatchery of Chittagong where the production of $M$. rosenbergii was done through probiotics based rearing system. The prawn juveniles were stocked at a size of $2 \mathrm{~g}$ to $3 \mathrm{~g}$ in the different ponds. In this experiment juveniles were stocked with three different stocking densities. In treatment $1(\mathrm{~T}-1)$ juveniles were stocked at a rate of $2 / \mathrm{m}^{2}$, in treatment 2 (T-2) at $3 / \mathrm{m}^{2}$ and in treatment 3 (T-3) at $4 / \mathrm{m}^{2}$.

\section{Feed and feeding}

In this experiment stocked juveniles were fed on a commercial pellet feed. Feeds were broadcasted evenly along the marginal areas of the pond. Pellet feeds were given at $3 \%$ to $15 \%$ of the body weight of prawn daily twice, where $60 \%$ to $75 \%$ of total feed should be fed at late evening of the day. Initially feeding was started at $15 \%$ of total biomass which was gradually reduced to $3 \%$ to $4 \%$ at the final stage of culture period.

\section{Probiotics application with feed}

In the present study, some replicates were practiced with probiotics mixed feed. At first the amount of feed was calculated required for those replicates for the day and then calculated the probiotics (Sanolife ${ }^{\circledast}$ Pro1) amount at a rate of $5 \mathrm{~g} / \mathrm{kg}$ feed. Probiotics was mixed with required amount of clean water to evenly spread over all the feed particles. Finally, probiotics mixed feed was kept for air drying and then applied to the pond.

\section{Probiotics application in pond water}

In this experiment threereplicates of each treatment was practiced with probiotics in pond water. Two commercial probiotics such as Sanolife ${ }^{\circledR}$ Pro-W and Biomin ${ }^{\star}$ Pondlife were used. Sanolife Pro-W powder was mixed with clean pond water and then evenly distributed directly to the pond water. For Biomoin ${ }^{\circ}$ Pond life the calculated amount of powder was kept for germination in a 20-liter clean water and $50 \mathrm{~g}$ of sugar mixed solution for 3 hours as per given instruction and then evenly distributed directly to the pond water.

\section{Statistical analysis}

$\mathrm{t}$ - test was done to find out the value of ' $\mathrm{p}$ ' by using software- $\mathrm{R}$ for the final average body weight, mean growth rate and gross production, where $p=0.04018, p=0.03503$ and $p=0.00036$ respectively. For all the three factors $\mathrm{p}$ value is smaller than 0.05 , which indicates the results are highly significant.

Pearson's product-moment correlation was done for correlation analysis of survival with stocking densities and found, $r=-0.98$ and $p=5.277 e-06 . r=-0.98$ indicates that, there is a high degree of negative association between stocking density and survival rate. That is as the stocking density increases the survival rate decreases. $\mathrm{P}=5.277 \mathrm{e}-06$ implies that the result is highly significant.

\section{Observations and Results}

\section{Growth, survival and production performance}

The experiment was carried out for 150 days. In the experiment T-1 $\left(2 / \mathrm{m}^{2}\right)$, the final average weight gain was $63.7 \mathrm{~g}$ and $55.7 \mathrm{~g}$ in probiotics based and non-probiotics based culture systems respectively, in experiment $\mathrm{T}-2\left(3 / \mathrm{m}^{2}\right)$, average weight gain were $55.7 \mathrm{~g}$ and $46.7 \mathrm{~g}$ and in experiment T-3 $\left(4 / \mathrm{m}^{2}\right)$, average weight gain were $43 \mathrm{~g}$ and $37 \mathrm{~g}$ in probiotics and non-probiotics based culture system respectively. Mean growth rates were found higher (Table 1) in probiotics then in nonprobiotics culture systems in all replicates.

In three treatments, the mean growth rates were recorded as 0.41 g, $0.36 \mathrm{~g}$ and $0.27 \mathrm{~g}$ per day in $\mathrm{T}-1, \mathrm{~T}-2$ and $\mathrm{T}-3$ treatments respectively for Sanolife ${ }^{\oplus}$ Pro-1 culture system. On the other hand, the average growth rates were recorded as $0.35 \mathrm{~g}, 0.30 \mathrm{~g}$ and $0.23 \mathrm{~g}$ per day in T-1, T-2 and T-3 treatments respectively with same stocking densities of non-probiotics culture system.

Survival rate of cultured $M$. rosenbergii found different with the same stocking densities among the probiotics and non-probiotics culture system. The highest average survival rates recorded were $69.3 \%$ and $68.3 \%$ (Table 2$)$ in T-1 $\left(2 / \mathrm{m}^{2}\right)$ for probiotics ponds and nonprobiotics ponds respectively. The lowest average survival rate of $58.3 \%$ and $57.7 \%$ (Table 2 ) was found in $\mathrm{T}-3\left(4 / \mathrm{m}^{2}\right)$ for probiotics and nonprobiotics ponds respectively.

Gross production from different culture systems also differs in probiotics and non-probiotics culture system. The estimated average gross production of $M$. rosenbergii in T-1 at a stocking density of $2 /$ $\mathrm{m}^{2}$ was calculated $87.23 \mathrm{~g} / \mathrm{m}^{2}$ and $74.62 \mathrm{~g} / \mathrm{m}^{2}$ (Table 2) per crop for probiotics and non-probiotics based culture system respectively. On the other hand, the estimated gross productionin T-2 at a stocking density of $3 / \mathrm{m}^{2}$ was found to be $103 \mathrm{~g} / \mathrm{m}^{2} / \mathrm{crop}$ and $87.23 \mathrm{~g} / \mathrm{m}^{2} / \mathrm{crop}$ 
Citation: Chowdhury IA, Das J, Das NG (2017) Development of Probiotics Based Culture System of Macrobrachium rosenbergii Using Different Stocking Densities. J Aquac Res Development 8: 494. doi: 10.4172/2155-9546.1000494

Page 3 of 4

\begin{tabular}{|c|c|c|c|c|c|c|c|c|c|c|}
\hline \multirow[b]{2}{*}{ Experiment } & \multirow{2}{*}{$\begin{array}{c}\text { Stocking } \\
\text { density (ind } / \\
\mathrm{m}^{2} \text { ) }\end{array}$} & \multirow{2}{*}{$\begin{array}{c}\text { Initial } \\
\text { average } \\
\text { body wt. (g) }\end{array}$} & \multicolumn{4}{|c|}{ Final average body wt. (g) } & \multicolumn{4}{|c|}{ Mean growth rate (g/day) } \\
\hline & & & $\begin{array}{c}\text { Sanolife }{ }^{\circledR} \\
\text { Pro-1 }\end{array}$ & Average & $\begin{array}{c}\text { Non- } \\
\text { probiotics }\end{array}$ & Average & $\begin{array}{c}\text { Sanolife }{ }^{\circledR} \\
\text { Pro-1 }\end{array}$ & Average & Non-probiotics & Average \\
\hline \multirow{3}{*}{$\mathrm{T}-1$} & 2 & 2.3 & 65 & \multirow{3}{*}{63.7} & 57 & \multirow{3}{*}{55.7} & 0.42 & \multirow{3}{*}{0.41} & 0.36 & \multirow{3}{*}{0.36} \\
\hline & 2 & 2.3 & 62 & & 54 & & 0.4 & & 0.35 & \\
\hline & 2 & 2.3 & 64 & & 56 & & 0.41 & & 0.36 & \\
\hline \multirow{3}{*}{ T-2 } & 3 & 2 & 55 & \multirow{3}{*}{55.7} & 46 & \multirow{3}{*}{46.7} & 0.34 & \multirow{3}{*}{0.35} & 0.29 & \multirow{3}{*}{0.3} \\
\hline & 3 & 2 & 56 & & 44 & & 0.36 & & 0.28 & \\
\hline & 3 & 2 & 56 & & 50 & & 0.36 & & 0.32 & \\
\hline \multirow{3}{*}{$\mathrm{T}-3$} & 4 & 2 & 44 & \multirow{3}{*}{43} & 37 & \multirow{3}{*}{37} & 0.28 & \multirow{3}{*}{0.27} & 0.23 & \multirow{3}{*}{0.23} \\
\hline & 4 & 2 & 42 & & 35 & & 0.27 & & 0.22 & \\
\hline & 4 & 2 & 43 & & 39 & & 0.27 & & 0.25 & \\
\hline
\end{tabular}

Table 1: Final body weight and mean growth rate of $M$. rosenbergii in probiotics and non-probiotics based culture system.

\begin{tabular}{|c|c|c|c|c|c|c|c|c|c|}
\hline \multirow[b]{2}{*}{ Experiment } & \multirow{2}{*}{$\begin{array}{l}\text { Stocking density } \\
\quad\left(\text { ind } / \mathrm{m}^{2}\right)\end{array}$} & \multicolumn{4}{|c|}{ Survival (\%) } & \multicolumn{4}{|c|}{ Gross Production (g/m²/crop) } \\
\hline & & $\begin{array}{c}\text { Sanolife }{ }^{\circledR} \\
\text { Pro-1 }\end{array}$ & Average & $\begin{array}{c}\text { Non- } \\
\text { probiotics }\end{array}$ & Average & $\begin{array}{c}\text { Sanolife }{ }^{\circledR} \\
\text { Pro-1 }\end{array}$ & Average & $\begin{array}{c}\text { Non- } \\
\text { probiotics }\end{array}$ & Average \\
\hline \multirow{3}{*}{$\mathrm{T}-1$} & 2 & 68 & \multirow{3}{*}{69.3} & 66 & \multirow{3}{*}{68.3} & 88.00 & \multirow{3}{*}{87.23} & 75.00 & \multirow{3}{*}{74.62} \\
\hline & 2 & 70 & & 69 & & 86.20 & & 75.25 & \\
\hline & 2 & 70 & & 70 & & 87.50 & & 73.60 & \\
\hline \multirow{3}{*}{$\mathrm{T}-2$} & 3 & 63 & \multirow{3}{*}{62.7} & 64 & \multirow{3}{*}{63.0} & 104.00 & \multirow{3}{*}{103.0} & 88.20 & \multirow{3}{*}{87.23} \\
\hline & 3 & 61 & & 60 & & 102.50 & & 79.20 & \\
\hline & 3 & 64 & & 65 & & 102.50 & & 94.30 & \\
\hline \multirow{3}{*}{$\mathrm{T}-3$} & 4 & 57 & \multirow{3}{*}{58.3} & 56 & \multirow{3}{*}{57.7} & 100.00 & \multirow{3}{*}{98.1} & 82.80 & \multirow{3}{*}{84.26} \\
\hline & 4 & 58 & & 58 & & 92.50 & & 81.20 & \\
\hline & 4 & 60 & & 59 & & 101.75 & & 88.78 & \\
\hline
\end{tabular}

Table 2: Survival and gross production of cultured $M$. rosenbergii in different culture systems.

(Table 2) for probiotics and non-probiotics culture system respectively. In treatment three (T-3) at stocking density of $4 / \mathrm{m}^{2}$ the final gross production was estimated to be $98.1 \mathrm{~g} / \mathrm{m}^{2} /$ crop for probiotics based culture system and $84.26 \mathrm{~g} / \mathrm{m}^{2} /$ crop (Table 2 ) for non-probiotics based culture system.

\section{Influence on water quality}

In the present study, the water parameters were recorded weekly basis in all ponds and found the recorded parameters within the range of Macrobrachium culture. Average water temperature range was from $29^{\circ} \mathrm{C}$ to $31^{\circ} \mathrm{C}$ in three replicates of all treatments pond which were found optimum for Macrobrachium culture. Average $\mathrm{pH}$ ranged from 8 to 8.2 in all ponds. Dissolved oxygen ranged from $4.8 \mathrm{mg} / \mathrm{l}$ to $5.5 \mathrm{mg} / \mathrm{l}$, ammonia ranged from $0.1 \mathrm{mg} / \mathrm{l}$ to $0.19 \mathrm{mg} / \mathrm{l}$. Nitrite concentration varied from $0.1 \mathrm{mg} / 1$ to $0.22 \mathrm{mg} / \mathrm{l}$ in all the replicates. Transparency also ranged from $33.5 \mathrm{~cm}$ to $35.25 \mathrm{~cm}$. Alkalinity ranged from $77 \mathrm{mg} / \mathrm{l}$ to $88 \mathrm{mg} / \mathrm{l}$. The variation of dissolved oxygen, $\mathrm{pH}$ and $\mathrm{N}$-ammonia was recorded throughout culture period. Among all the three treatments, only some selected T1R3, T2R3 and T3R3 treatments were practiced with probiotics application in pond water. In those cases, ammonia and nitrite were variable results (Table 3 ) by the probiotics application. Due to the probiotics action waste feed and other waste matters were degraded more than other treatments those were practiced without probiotics. As a result, the concentration of toxic gases in those ponds was reduced in some extent. In all those three treatments ammonia and nitrite concentration found less (Table 3, highlighted value) compare to other treatments among the three different stocking density groups.

\section{Discussion}

Probiotics used in feed and pond water has a significant role in the growth of prawn culture. In the present experiment, it was found that in every replicate of the three different treatments higher growth and higher net gross production were found from the probiotics treated pond. The present may be compared with the following authors. ZiaeiNejad et al. [4] and Wang [5] reported the benefits of the probiotics supplements improved feed value, enzymatic contribution to digestion, inhibition of pathogenic microorganisms, anti-mutagenic and anticarcinogenic activity, growth promoting factors, and increase immune response. Dalmin et at. [6] reported that use of Bacillus sp. improved water quality, survival, growth rates and health status of the juveniles of $P$. monodon and reduced the pathogenic vibrios. Keysami et al. [7] mentioned that prawns gained higher weight and better FCR by using B. subtilis in feed.

In the present experiment, different survival rates were recorded in different treatments. Higher survival rate $69.3 \%$ was found where the stocking density was maintained at $2 / \mathrm{m}^{2}$ and in this treatment average growth was also recorded higher in probiotics based treatment. In other two treatments, stocking density $\left(3 / \mathrm{m}^{2}\right)$ and $\left(4 / \mathrm{m}^{2}\right)$ showed lower survival as well as lower growth than the treatment with $2 / \mathrm{m}^{2}$ stocking density. On the other hand, the average final body weights in three treatments were $55.7 \mathrm{~g}, 46.7 \mathrm{~g}$ and $37 \mathrm{~g}$ respectively for T-1, T-2 and T-3. Among three treatments the best result was found at treatments 2 where stocking density was maintained $3 / \mathrm{m}^{2}$. Balcazar et al. [8]; Gullian et al. [9] reported that prawn's survival was also found significantly greater in $B$. subtilis treated groups than in the control group. It is possible that this phenomenon operates by the substitution of opportunist pathogens that reduced growth.

It was found that the final body weight gained $63.7 \mathrm{~g}$ and $55.7 \mathrm{~g}$ in Sanolife ${ }^{\oplus}$ Pro- 1 and non-probiotics based culture systems respectively in T-1 treatment $\left(2 / \mathrm{m}^{2}\right)$. Similarly, the body weight gained $55.7 \mathrm{~g}$ and $46.7 \mathrm{~g}$ in $\mathrm{T}-2\left(3 / \mathrm{m}^{2}\right)$ and $43 \mathrm{~g}$ and $37 \mathrm{~g}$ in $\mathrm{T}-3\left(4 / \mathrm{m}^{2}\right)$ in probiotics and non-probiotics treatment respectively. It was found from the above results that body weight was higher in lower stocking densities and lower in higher stocking densities. Siddiqui et al. [10] and Karplus and Sagi [11] reported in their research that, the prawn response to higher 


\begin{tabular}{|c|c|c|c|c|c|c|c|}
\hline Experiments & Temp. $\left({ }^{\circ} \mathrm{C}\right)$ & $\mathrm{pH}$ & $\mathrm{DO}(\mathrm{mg} / \mathrm{l})$ & $\mathrm{NH}_{3}(\mathrm{mg} / \mathrm{l})$ & $\mathrm{NO}_{2}(\mathrm{mg} / \mathrm{l})$ & Transparency (cm) & Alkalinity (mg/l) \\
\hline T1R1 & 29.65 & 8 & 5.49 & 0.125 & 0.1 & 35.25 & 77 \\
\hline T1R2 & 29.95 & 8.01 & 5.12 & 0.19 & 0.18 & 35.5 & 80 \\
\hline T1R3 & 30.4 & 8.1 & 4.96 & 0.15 & 0.1 & 36 & 83 \\
\hline $\mathrm{T} 2 \mathrm{R} 1$ & 30.1 & 8.12 & 5.35 & 0.155 & 0.18 & 39.75 & 86 \\
\hline T2R2 & 30 & 8.16 & 5.09 & 0.13 & 0.22 & 34.5 & 88 \\
\hline T2R3 & 30.7 & 8.1 & 4.9 & 0.1 & 0.15 & 35.5 & 81 \\
\hline T3R1 & 29.7 & 8.11 & 5.41 & 0.165 & 0.18 & 36 & 82 \\
\hline T3R2 & 30.05 & 8.06 & 5.03 & 0.15 & 0.2 & 34.25 & 82 \\
\hline T3R3 & 30.85 & 8.2 & 4.8 & 0.12 & 0.15 & 35 & 81 \\
\hline
\end{tabular}

Table 3: Average water parameters of different experimental ponds.

density uneven increase in number of small males. According to FAO [12], lower to higher yield of species depends on three different culture systems related to stocking density.

Improved water quality has an especial affinity with the pobiotics. It was reported by Dalmin et al. [6] that use of Bacillus sp. improves the water quality, survival, growth rates and the health status of juvenile $P$. monodon and reduced the pathogenic vibrios. Average water temperature ranges from $29^{\circ} \mathrm{C}$ to $31^{\circ} \mathrm{C}$ and $\mathrm{pH}$ from $8-8.2$ in all three treatments of the experimental ponds are suitable for Macrobrachium culture. Timmons et al. [13] recommended $\mathrm{pH}$ level ranging from 6.5 to 8.5 for aquaculture, while Boyd and Zimmerman [14] recommended $\mathrm{pH}$ level from 7.0 to 8.5 as ideal for $M$. rosenbergii production. Dissolved oxygen is one of the important factors which limit the intensification of freshwater prawn culture. In the present study DO was recorded $4.8 \mathrm{mg} / \mathrm{L}$ to $5.49 \mathrm{mg} / \mathrm{L}$ which was in optimum level for prawn culture. Timmons et al. [13] recommended DO level above $5 \mathrm{mg} / \mathrm{L}$ for $M$. rosenbergii culture, while Boyd and Zimmerman [14] reported that $M$. rosenbergii can tolerate $2 \mathrm{mg} / \mathrm{L}$ with no stress, and level below $1 \mathrm{mg} / \mathrm{L}$ start to cause mortality. Ammonia ranges from $0.1 \mathrm{mg} / \mathrm{L}$ to $0.19 \mathrm{mg} / \mathrm{L}$ in different ponds in the present study. At the same time nitrite concentration varied from $0.1 \mathrm{mg} / \mathrm{L}$ to $0.22 \mathrm{mg} / \mathrm{L}$ in different water samples. Timmons et al. [13] recommended nitrite level below $1,000 \mathrm{mg} / \mathrm{L}$ for aquaculture systems, while New [15] stated that concentration under $2,000 \mathrm{mg} / \mathrm{L}$ is adequate for $M$. rosenbergii. But in this experiment, observed levels were lower than the results mentioned above. Low nitrite concentration indicates that released ammonia is rapidly assimilated by phytoplankton and nitrification is adequately occurred. Therefore, results suggest that both nitrification and photosynthesis were not negatively affected by intensification. According to Wang et al. [16] showed that the use of commercial probiotics in $P$. vannamei ponds can reduce the concentrations of nitrogen and phosphorus that increase the shrimp yields. In this study alkalinity ranges from $77 \mathrm{mg} / \mathrm{L}$ to $88 \mathrm{mg} / \mathrm{L}$. Boyd and Tucker [17] stated that alkalinity has an indirect effect on organisms, making $\mathrm{pH}$ stable, increasing water fertility and decreasing toxic potential of metals. Timmons et al. [13] recommend alkalinity range from 50 $\mathrm{mg} / \mathrm{L}$ to $300 \mathrm{mg} / \mathrm{L}$ in aquaculture ponds. On the other hand, Boyd and Zimmerman [14] and New [15] recommended the values between 20 $\mathrm{mg} / \mathrm{L}$ and $60 \mathrm{mg} / \mathrm{L}$ for $M$. rosenbergii culture. Transparency is related to the quantity of suspended materials. Boyd and Zimmerman [14] and New [15] recommended transparency values from $25 \mathrm{~cm}$ to $60 \mathrm{~cm}$ for $M$. rosenbergii culture. In the present study, the transparency was recorded from $35 \mathrm{~cm}$ to $39.75 \mathrm{~cm}$ which is good for prawn culture.

\section{Conclusion}

The technical potentials of prawn (M. rosenbergii) polyculture using probiotics based system were investigated in this study. This study demonstrated that pond prawn production was significantly increased with the introduction of probiotics. Prawn stocking in monoculture has the potentials of increasing total yields as well as farm income with probiotics application. Some ecological advantages of probiotics based prawn culture, such as improved water quality help to increase the sustainability of this system of aquaculture.

\section{References}

1. New MB, D'Abramo LR, Valenti WC, Singholka S (2000) Sustainability of freshwater prawn culture. freshwater prawn culture: The farming of Macrobrachium rosenbergii, Blackwell Science Ltd, Oxford, UK.

2. Ahmed N (2005) The role of women in freshwater prawn farming in Southwest Bangladesh. Fish Farmer 28: 14-16.

3. Maeda M (1999) Microbial processes in aquaculture, National Research Institute of Aquaculture, Nansei, Mie 516-0193, Japan.

4. Ziaei-Nejad S, Rezaei MH, Takami GA, Lovett DL, Mirvaghefi AR, et al. (2006) The effect of Bacillus spp. bacteria used as probiotics on digestive enzyme activity, survival and growth in the Indian white shrimp Fenneropenaeusindicus. Aquaculture 252: 516-524.

5. Wang YB (2007) Effect of probiotics on growth performance and digestive enzyme activity of the shrimp Penaeusvannamei. Aquaculture 269: 259-264.

6. Dalmin G, Kathiresan K, Purushothaman A (2001) Effect of probiotics on bacterial population and health status of shrimp in culture pond ecosystem. Indian J Exp Biol 39: 939-942.

7. Keysami MA, Mohammadpour M, Saad CR (2012) Probiotic activity of Bacillus subtilis in juvenile freshwater prawn, Macrobrachium rosenbergii (de Man) at different methods of administration to the feed. Aquaculture Int 20: 499-511.

8. Balcazar JL, De Blas I, Ruiz-Zarzuela I, Vendrell D, Uzquiz JL (2004) Probiotics: A tool for the future of fish and shellfish health management. J Aquac Trop 19 239-242.

9. Gullian M, Thompson F, Rodriguez J (2004) Selection of probiotic bacteria and study of their immune-stimulatory effect in Penaeusvannamei. Aquaculture 233: 1-14.

10. Siddiqui AQ, Al-Hinty HM, Ali SA (1995) Effects of harvesting methods on populations structure, growth and yield of freshwater prawn Macrobrachium rosenbergii cultured at two densities. J Appl Aquaculture 5: 9-19.

11. Karplus I, Sagi A (2010) The biology and management of size variation, WileyBlackwell Science, Blackwell Publishing, London, UK.

12. http://www.fao.org/fi/glossary/aquaculture/default.asp?lang=en

13. Timmons MB, Ebeling JM, Weathon FW, Summerfelt ST, Vinci BJ (2002) Recirculating aquaculture system, (2nd edn). Cayuga Aqua Ventures, Ithaca, New York, USA.

14. Boyd CE, Zimmermann S (2000) Grow out systems: Water quality and soil management, freshwater prawn farming: The farming of Macrobrachium rosenbergii, Blackwell Science, Oxford, UK.

15. New MB (2002) Farming freshwater prawns- A manual for the culture of the giant river prawn (Macrobranchium rosenbergii). Aqua Res 34: 1109-1110.

16. Wang YB, Xu ZR, Xia MS (2005) The effectiveness of commercial probiotics in Northern white shrimp (Penaeusvannamei L.) ponds. Fish Sci 71: 1034-1039.

17. Boyd CE, Tucker CS (1998) Pond aquaculture water quality management, Kluwer Academic Publishers, Netherlands. 